[Agr. Biol. Chem., Vol. 25, No. 8. p. 605 610, 1961]

\title{
Studies on the Organophosphorus Insecticides
}

\author{
Part VII. Chemical and Biological Properties of New Low Toxic \\ Organophosphorus Insecticide. O, O-Dimethyl-O-(3-methyl- \\ 4-nitrophenyl) Phosphorothioate \\ By Yoshihiko Nishizawa, Kuniyoshi FujiI, Tadaomi Kadota, \\ Junshi Miyamoto and Hideo Sakamoto \\ Laboratory of Sumitomo Chem. Co., Ltd., Osaka
}

Received March 28, 1961

\begin{abstract}
In the previous paper ${ }^{1)}$, it has been reported that $\mathrm{O}, \mathrm{O}$-dimethyl-O-(3-methyl-4-nitrophenyl) phosphorothioate (commercial name, Sumithion) has not only an extremely low toxicity but also a superior activity towards insects, compared with any other isomers, homologues and analogues. In this paper, the chemical and the biological properties of Sumithion will be reported in detail.
\end{abstract}

It has been well known that phosphorothioates*1) having 4-nitrophenyl group therein possess a high degree of insecticidal activity and consequently are very useful as an active ingredient of agricultural chemicals. However, they have at the same time, a very high degree of toxicity towards mammals and this is, indeed, a serious defect of these compounds for practical application. Therefore, many attempts have been made to search for the compound having lower toxicity and higher insecticidal activity by the American and the German researchers and compounds such as Chlorthion $^{2)}$ and Dicapton ${ }^{3)}$ have been found as the results of their efforts.

Although the so-called low toxic insecticides mentioned above really have comparatively low toxicity, they become also inferior in their

\footnotetext{
1) Y. Nishizawa et al., This Journal, 25, 597 (1961).

*1) Chemical names of phosphorus compounds in this paper were based upon the Drake Committec's Report (Chem. Eng. News, 30, 4515 (1952)).

2) G. Schrader, Ang. Chem., 66, 265 (1954).

3) American Cyanamid Co., Jap. Pat. Announced No. 6170 (1951), 3449 (1952).
}

insecticidal activities, especially towards rice stem borer.

In this Laboratory, various studies have been made for the purpose of obtaining a compound which has a low toxicity and also a high degree of insecticidal activity towards rice stem borer, since such compound is anxiously wanted in rice producing districts. As the results, the present authors and their co-workers have succeeded, as already reported, in obtaining two new compounds which have not only the extremely low toxicities but also the superior activities towards insects, compared with any conventional insecticidal compounds or their isomers, homologues and analogues. In this paper, chemical and biological properties of Sumithion which is one of the new low toxic insecticides will be reported in detail.

\section{Chemical Properties of Sumithion.}

Sumithion is prepared in good yield from 3-methyl-4-nitrophenol or its alkaline metal salt and O,O-dimethyl phosphorochloridothio- 
ate as already reported in previous paper ${ }^{1)}$.

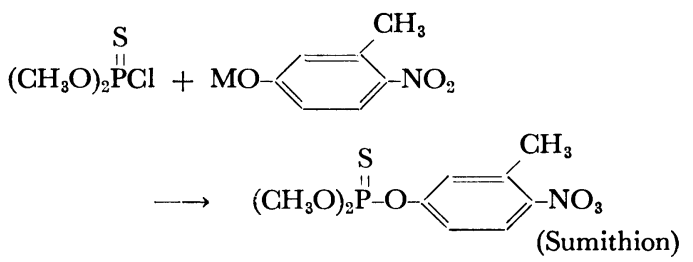

$\mathbf{M}$ is hydrogen atom or alkaline metal atom.

The distillation of Sumithion causes its isomerization even under a reduced pressure and produces O-methyl-S-methyl-O- (3-methyl4-nitrophenyl) phosphorate, but does not cause explosion contrary to that of methylparathion.

Pure Sumithion is obtained by silicagel column chromatography in carbontetrachloride solution and shows the refractive index $n_{\mathrm{D}}^{25} 1.5528$ and the specific gravity $d_{4}^{25} 1.3227$.

Sumithion is, in pure state, pale yellow in color and easily soluble in alcohols, ethers, ketones, esters or cyclichydrocarbons and hardly soluble in chain-hydrocarbons and water.

Stability of Sumithion in the alkaline aqueous solution was studied by colorimetric determination of 3-methyl-4-nitrophenol liberated during incubation with sodium hydroxide solution and was compared with that of methyl and ethylparathion.

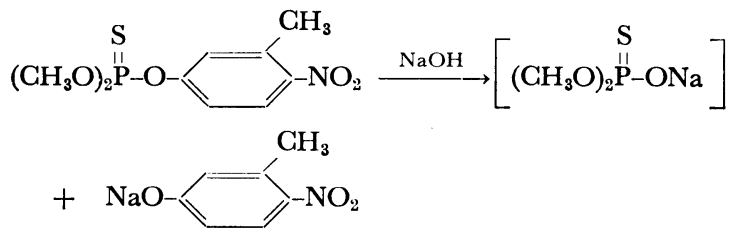

The hydrolysis did not proceed proportionally with time, but the process was represented by the second order reaction, under the conditions tested, first order relative to the concentration of organophosphorus compound, and first order relative to the sodium hydroxide. 'The second order rate constant and the half-life times of methyl-, ethyl-parathion and Sumithion are shown in Table I and II.

TABle I. The Second ORder Rate Const.*2) of SUMITHION IN ALKaline SOlUTion

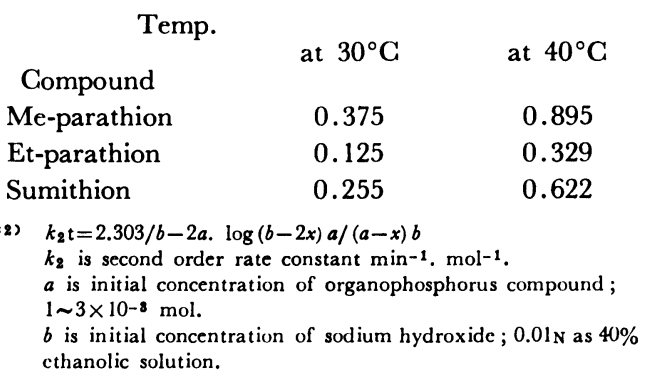

TABle II. The HALF-Life Times OF SUMithion IN ALKaLINE SOLUTION Temp.

$\begin{array}{lll}\text { Compound } & \text { at } 30^{\circ} \mathrm{C} & \text { at } 40^{\circ} \mathrm{C} \\ \text { Me-parathion } & 210 \mathrm{~min} & 84 \mathrm{~min} \\ \text { Et-parathion } & 490 & 250 \\ \text { Sumithion } & 272 & 123\end{array}$

It is clear from Table I and II that Sumithion is one half time more stable than methylparathion.

The infrared spectrum and the ultraviolet spectrum of Sumithion are shown in Fig. 1 and 2, respectively. Frequency of P-O-C (arom.) stretching vibration of Sumithion is $1233 \mathrm{~cm}^{-1}$ although that of methylparathion is $1215 \mathrm{~cm}^{-1}$, therefore, it may be considered that the distance of P-O-C (arom.) linkage of Sumithion is shorter than that of methylparathion (see Fig. 1).

In ultra-violet spectra, $\lambda_{\max }\left(\varepsilon_{\max }\right)$ of methylparathion is at $273(9474)$ but that of Sumithion is at $268.5(6756)$. This difference in the wavelength and the molecular extinction coefficient of absorption maximum shows clearly that the steric hindrance between methyl group and nitro group in phenyl group of Sumithion is relatively larger (see Fig. 2) . 


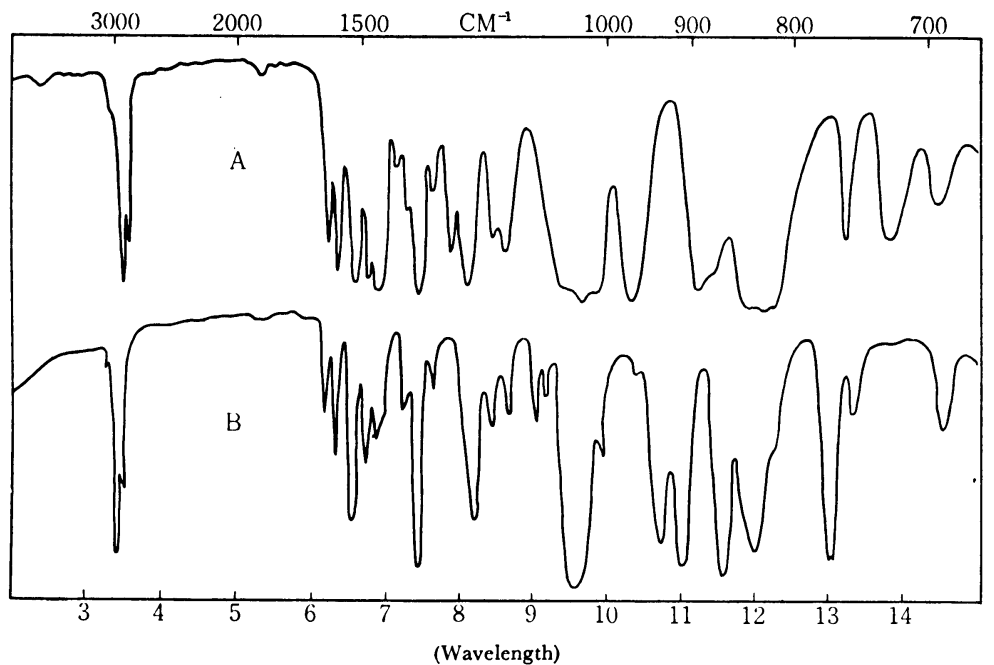

Fig. 1. The Infrared Absorption Spectra of Sumithion and Methyl Parathion. (in Nujol, by Shimadzu IR Infrared Spectrophotometer.)
A : Sumithion
B : Me-parathion

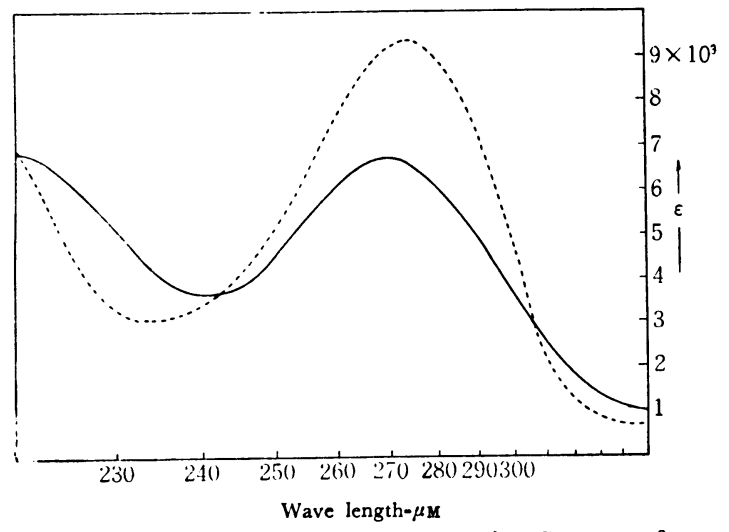

FIG. 2. The Ultra-violet Absorption Spectra of Sumithion and Methyl Parathion.

(in Ethanol, by Shimadzu RS-27 Recording Spectrophotometer.)

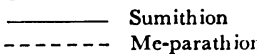

\section{Biological Activities of Sumithion.}

Pure Sumithion has not inhibitory power towards acetyl-cholinesterase but is converted easily to the oxo-form by enzymatic oxidation in vivo and this oxo-Sumithion has high inhibitory power.

The inhibitory potency of oxo-Sumithion<smiles>CO[Pb](=S)Oc1ccc([N+](=O)[O-])c(C)c1</smiles><smiles>COP(=O)(OC)Oc1ccc([N+](=O)[O-])c([N+](=O)[O-])c1</smiles>

TABLE III. INHIBITORY POTENCY OF OXO-SUMITHION TOWARDS ACETYLCHOLINESTERASE*3)

$\begin{array}{llr}\quad \text { Compound } & \text { Fly head } & \text { Mouse brain } \\ \text { Me-paraoxon } & 2.2 \times 10^{-5 * 4)} & 1.0 \times 10^{-5} \\ \text { Et-paraoxon } & 3.2 \times 10^{-6} & 2.6 \times 10^{-6} \\ \text { Oxo-Sumithion } & 5.0 \times 10^{-6} & 2.8 \times 10^{-5}\end{array}$

*8) Inhibition of fly head and mouse brain acetylcholinesterase by these compounds was investigated manometrically at $\mathrm{pH} 7.6$, $37.5^{\circ} \mathrm{C}$ by using a homogenate of mouse brain and a supernatant from the homogenate of the adult house fly heads by centrifugation at $6,000 \mathrm{rpm}$ for $7 \mathrm{mins}$. Acetylcholine perchlorate $\left(5 \times 10^{-8} \mathrm{~mol}\right.$.) was used as substrate. The inhibitor and the substrate were added simultaneously to the enzyme solution and the initial velocity observed was compared with that of the control. The inhibitory potency was determined by plotting the percent inhibition versus$\log$ of the inhibitor concentration.

*t) Mol. concentration required to cause $50 \%$ inhibition.

towards fly head and mouse brain acetylcholinesterase is shown in Table III.

The toxicity of Sumithion towards mouse is compared with that of parathion, varying 
TABLE IV. TOXICITY OF SUMITHION TOWARDS MousE*5) $\left(\mathrm{LD}_{50}\right.$ value)

\begin{tabular}{|c|c|c|}
\hline Route & Sumithion & Parathion \\
\hline Oral administration $* s)$ & $870 \mathrm{mg} / \mathrm{kg}$ & $9.5 \mathrm{mg} / \mathrm{kg}$ \\
\hline $\begin{array}{l}\text { Subcutaneous administra- } \\
\text { tion*7) }\end{array}$ & $1000 \mathrm{mg} / \mathrm{kg}$ & $11.5 \mathrm{mg} / \mathrm{k}$ \\
\hline $\begin{array}{l}\text { Intraperitoneal administra- } \\
\text { tion } * 8)\end{array}$ & $280 \mathrm{mg} / \mathrm{kg}$ & $6.0 \mathrm{mg} / \mathrm{kg}$ \\
\hline Dermal application $* 9$ ) & $\begin{array}{l}50 \mathrm{mg} / \text { one } \\
\text { mouse }\end{array}$ & $\begin{array}{r}0.81 \mathrm{mg} / \text { one } \\
\text { mouse }\end{array}$ \\
\hline
\end{tabular}

*5) The test was applied to each group of $10 \sim 15$ bodies of mice which had almost the same body weights ranging from 13 to 18 grams and were abstained from food for 4 hours before beginning the test.

*6) The test of the oral toxicity was conducted by the same method as in the previous paper 4

*7) The test by subcutaneous administration route was conducted as follows. Fach test compound was emulsified by dilution of $50 \%$ emulsifiable concentrate composition with water. Each concentration of the above solutions was injected subcutaneously. The volume of instilment was $50 \mathrm{ml}$ per $1 \mathrm{~kg}$ of body weight of mice. After keeping it for 5 days, the symptoms of poisoning were observed and $\mathrm{LD}_{5} 0(\mathrm{mg} / \mathrm{kg})$ value was calculated according to the Litchfield and Wilcoxon $\left.{ }^{5}\right)$ or Behrens-Käber $\left.{ }^{6}\right)$ methods.

*8) The test by the intraperitoneal administration route was conducted by almost the same process as that of subcutaneous route. But in this case, the test emulsion was injected into peritoneum and the symptoms of poisoning was observed for 3 days.

*9) The test of dermal application was conducted as follows. Each concentration of the aforesaid emulsion was spread on the skin of the back of a mouse, cutting the hair in $1 \mathrm{~cm}^{2}$ area and the spread part was covered wih a piece of cellophane ${ }^{7)}$. The volume of the emulsion applied was $0.05 \mathrm{ml}$ per one mouse. The symptoms of poisoning was observed for 7 days and LD $L_{50}$ value was calculated by the aforesaid method.

TABLE V. ORAL TOXICITY OF SUMITHION TOWARDS VARIOUS ANIMALS*10)

\begin{tabular}{|c|c|c|}
\hline Animals & Sumithion & Parathion \\
\hline Rats 全 & $\begin{array}{l}242 \\
433\end{array}$ & $\begin{array}{r}8.5 \\
10.0\end{array}$ \\
\hline Guinea pigs & 1833 & 12.5 \\
\hline Cats & 142.3 & 0.93 \\
\hline
\end{tabular}

*10) A suspension of the test compound was prepared by diluting the $5 \%$ gum arabic composition with water and was applied to each group of $3 \sim 5$ bodies of rats, guinea pigs or cats which had almost the same body weights ranging $130 \sim 170 \mathrm{~g}$ in rats, $200 \sim$ $250 \mathrm{~g}$ in guinea pigs and $2.0 \sim 3.0 \mathrm{~kg}$ in cats and had been abstained from food for 4 hours before begining the test.

their administration routes and the results are shown in Table IV.

Furthermore an outstanding characteristic of low toxicities of Sumithion will be apparent from the following Table VI.

The following Table VII shows the toxicity

4) Y. Nishizawa et al., Bôtyu-Kagaku, 26, 4 (1961).

5) J. T. Litchfield et al., J. pharmacol., 96, 99 (1949).

6) B. Behrens et al., Arch. exp. path. und pharmakol., 177, 379 (1935) .

7) T. Seki, Yakugaku Kenkyu, 23, 138 (1951).

\section{TABLE VI. The ORAL TOXICITIES OF Sumithion AND COMMERCIAL INSETICIDES}

Name Formula

Oral Toxicities towards Mouse $\mathrm{LD}_{50} \mathrm{mg} / \mathrm{kg}$

Sumithion<smiles>CO[PH](=S)Oc1ccc([N+](=O)[O-])c(C)c1</smiles>

Parathion<smiles>CCO[PH](=S)Oc1ccc([N+](=O)[O-])cc1</smiles>

Me-

Parathion<smiles>CO[PH](=S)Oc1ccc([N+](=O)[O-])cc1</smiles>

EPN<smiles>CCOP(=S)(Oc1ccc([N+](=O)[O-])cc1)c1ccccc1</smiles>

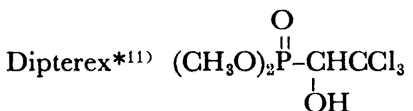

Chlorthion<smiles>CO[P+](=S)Oc1ccc([N+](=O)[O-])c(Cl)c1</smiles>

Dicapton

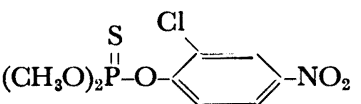

*11) Dipterex was produced to aqueous solution and used.

\section{TABLE VII. ThE TOXICITY*12) OF SUMITHION TOWARDS GOLDFISH}

Compound $10 \mathrm{ppm} . \quad 5 \mathrm{ppm} .2 \mathrm{ppm} .1 \mathrm{ppm}$.

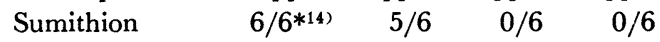

$\begin{array}{lllll}\text { Parathion } & 6 / 6 & 6 / 6 & 1 / 6 & 0 / 6\end{array}$

Contrast*13)

$0 / 6$

$0 / 6$

$0 / 6$

$0 / 6$

*12) It this test, an emulsion of the the test compound was made by dilution of $50 \%$ emulsifiable concentrate composition (comprised of 50 parts active ingredient, 30 parts Triton $X-100$ and 20 parts Xylene, by wcight) with water. An emulsion was applied to 6 goldfish in 101 of water. After keeping it for 70 hours, its death was recorded. All the goldfish used in this test had nearly the same body length of $4 \sim 5 \mathrm{~cm}$.

*18) Contrast means a solution without the test compound.

*16) A numerator shows the number of dead bodies of goldfish and a denominator shows the number of total bodies used in this test.

towards goldfish (Carassius auratas). It will be evident from Table VII that Sumithion has almost the same toxicity towards goldfish as parathion. 
TABle VIII. TOPICAL APPLICATION*15) OF SUMITHION TOWARDS HIBERNATING LARVAE OF RICE STEM BORER (kill \%)

$\begin{array}{llllll}\text { Compound } & 20 \gamma / & 6.7 \gamma / & 2 \gamma / & 0.67 \gamma / & 0.2 \gamma / \\ \text { Sumithion } & 10 \text { larva } & \text { larva } & \text { larva } & \text { larva } & \text { larva } \\ \text { Parathion } & 100 \% & 100 \% & 100 \% & 100 \% & 60 \% \\ & 100 \% & 100 \% & 90 \% & 50 \%\end{array}$

*15) Topical test was conducted as follows. Each compound was dissolved in acetone to prepare a series of acetone solutions containing from 0.067 to $2 \%$ of the each compound $(\mathrm{g} / \mathrm{ml})$.

Each $1 / 1000 \mathrm{ml}$ of the said solution was applied to the body of the larva by means of micrometer syringe and, after kecping it for 3 days at $25^{\circ} \mathrm{C}$, its death or survival condition was observed. The larvae utilized in this test had almost the same body weights ranging $80 \sim 90 \mathrm{mg}$ and each solution was applied to a group of 20 larvae in order to calculate the mean fatal per cent.

TABLE IX. POT-TEST*16) OF SUMITHION TOWARDS THE First Generated LARVAE OF RICE STEM BORER (kill \%)

(Spray 3 days later from the encroachment)

$\begin{array}{lllll}\text { Compound } & \times 2000 & \times 4000 & \times 8000 & \times 16000 \\ \text { Sumithion } & 97.7 \% & 81.4 \% & 60.4 \% & 56.9 \% \\ \text { Parathion } & 80.2 \% & 75.6 \% & 52.1 \% & 49.9 \%\end{array}$

*16) The pot-test towards the first generated larvac was conducted by the same method as the previous paper ${ }^{8)}$, but the rice plants elapsing further $15 \sim 25$ days after transplanting into a porcelain pot, were used.
TABLE X. POT-TEST*17) OF SUMITHION TOWARDS THE SECOND GENERATED LARVAE OF RICE STEM BORER (kill \%)

Compound $\times 1,000 \times 2,000 \times 4,000$

Spray 2 days later Sumithion $99.7 \% \quad 99.8 \% \quad 95.2 \%$ from encroachment Parathion $99.5 \quad 87.0 \quad 86.4$ Spray 3 days later Sumithion $98.6 \quad 96.5 \quad 86.5$ from encroachment Parathion $100 \quad 100 \quad 95.4$ Spray 4 days later Sumithion $100 \quad 100 \quad-$ from encroachmeht Parathion 91.5 55.6 -

*17) The pot-test towards the second generated larvae was conducted by the same method as the previous paper ${ }^{8)}$.

\section{Insecticidal Activities of Sumithion.}

The following Table VIII, IX and $\mathrm{X}$ show the comparative efficacies towards rice stem borer (Chilo suppressalis WALKER) of Sumithion and of parathion which is the typical insecticidal compound utilized in these days.

In order to make clear the effectiveness of Sumithion towards sanitary pests, Table XI shows the comparative efficacies towards house fly and its larva (maggot), of Sumithion and

Table Xi. Insecticidal ACtivity of Sumithion towards Hous Fly aNd MagGot.*18)

\begin{tabular}{|c|c|c|c|c|c|c|c|c|c|}
\hline \multirow[b]{2}{*}{ Compound } & \multirow{2}{*}{$\begin{array}{l}\text { Conc.*19) } \\
\mathrm{g} / 100 \mathrm{ml} .\end{array}$} & \multirow{2}{*}{$\begin{array}{l}\text { Adult fly*20 } \\
\text { kill } \%\end{array}$} & \multirow{2}{*}{$\begin{array}{c}\text { Maggot*21) } \\
\text { kill \% }\end{array}$} & \multicolumn{6}{|c|}{ Spraying to generative place*22) } \\
\hline & & & & the day & $\begin{array}{l}\text { after } \\
1 \text { day }\end{array}$ & $\begin{array}{l}\text { after } \\
2 \text { days }\end{array}$ & $\begin{array}{l}\text { after } \\
3 \text { days }\end{array}$ & $\begin{array}{l}\text { after } \\
4 \text { days }\end{array}$ & $\begin{array}{l}\text { after } \\
7 \text { days }\end{array}$ \\
\hline Sumithion & 0.25 & 99.5 & 98.4 & 100 & 89.2 & 85.2 & 81.3 & 73.0 & 15.1 \\
\hline Malathion & 1.00 & 99.5 & 95.0 & 100 & 78.5 & 59.2 & 43.0 & 36.9 & 12.8 \\
\hline Diazinon & 0.125 & 99.5 & 99.0 & 100 & 93.6 & 84.0 & 91.3 & 87.2 & 50.0 \\
\hline Dipterex & 0.5 & 67.6 & 97.4 & 100 & 97.0 & 51.3 & 25.2 & 8.2 & - \\
\hline DDVP & 0.5 & 99.5 & 94.7 & 98.8 & 85.2 & 18.1 & 8.2 & - & - \\
\hline Dicapton & 0.25 & 100 & 93.8 & 100 & 93.5 & 61.8 & 52.6 & 44.6 & 12.3 \\
\hline Dimethoate & 0.0312 & 63.9 & 98.2 & 96.7 & 96.3 & 95.5 & 100 & 98.5 & 65.3 \\
\hline untreated & - & 8.6 & 3.5 & 1.7 & 0.6 & 0.8 & 2.0 & 2.3 & 2.1 \\
\hline
\end{tabular}

*18) In this test, an emulsifiable concentrate was prepared by mixing 50 parts of an active ingredient, 30 parts of Triton x-100 and 20 parts of xylene by weight, and the concentrate was diluted with water to make a test emulsion.

*19) The concentration, $\mathrm{g} / 100 \mathrm{ml}$, shows the amounts $(\mathrm{g})$ of the active ingredient present in $100 \mathrm{ml}$ of the test emulsion, and these values shown in this item were adequately chosen so that the kill \% of maggot came to more than $90 \%$.

*20) By means of settling tower method (cf. Bull. Ent. Res., 14, 223 (1924)).

*21) By means of the Beaker method. That is, a culture ground of house fly was settled into a beaker having an inner diameter of about $9 \mathrm{~cm}$ and a height of about $10 \mathrm{~cm}$, and eggs of house fly were blowed thereon. Two days later, $1 \mathrm{ml}$ of the test emulsion was sprayed on the surface of the ground, and after 7 days the dead and the surviving numbers of the larvae (maggots) were calculated.

*22) About $300 \mathrm{~g}$ of matured culture medium for the larva (maggot) of house fly were taken in a dish having an inner diameter of about $15 \mathrm{~cm}$ and a height of about $8 \mathrm{~cm}$, and $5 \mathrm{~g}$ of sugar was added thereto and mixed well. To the dish, which was regarded as an artificial generative place, $1 \mathrm{ml}$ of the test emulsion was sprayed. After that, adult flies were put therein every day and their vital states were observed. This experiment is concerned with the residual effectiveness of the test compound. 
Table XII. Insecticidal Activity of Sumithion towards many Pests

Pest

Chrysanthemum aphid

Green peach aphid

Green leafhopper

Green rice leavhopper

Black rice bug

Common Cabbage Worm cabbage
Crop

Chrysanthemum

Radish

Rice

Rice

Rice
Formulation

$\left.50 \mathrm{E}^{* 23}\right)$

$50 \mathrm{E}$

$50 \mathrm{E}$

$50 \mathrm{E}$

$50 \mathrm{E}$

$50 \mathrm{E}$
Conc. of the actual ingredient

$1 / 16,000$
$1 / 16,000$
$1 / 2,000$
$1 / 6,000$
$1 / 2,000$
$1 / 4,000$

Type of application spray spray spray spray spray foliaye spray
Effect $100 \%$ kill $100 \%$ kill $100 \%$ kill $100 \%$ kill $100 \%$ kill effective 10 days later

*28) $50 \mathrm{E}$ means an emulsifiable concentrate containing 50 parts of Sumithion, 20 parts of xylene and 30 parts of Triton $\mathrm{x}-100$ by weight.

of the conventionally utilized low toxic insecticides.

The following Table XII shows the insecticidal activity of Sumithion towards other pests than the above described injurious insects.
Acknowledgement. The authors wish to express their thanks to Sumitomo Chem. Co., Ltd. for permission to publish this work. They are indebted to many coworkers in the Laboratory for their earnest assistances. 